\title{
新时代爱国主义教育贯穿高校国防教育工作的实践探索 一以沈阳师范大学为例
}

\author{
Practical Exploration of Patriotism Education Running Through the Work of \\ National Defense Education in Colleges and Universities in the New Era \\ — Taking Shenyang Normal University as an Example
}

张英

Ying Zhang

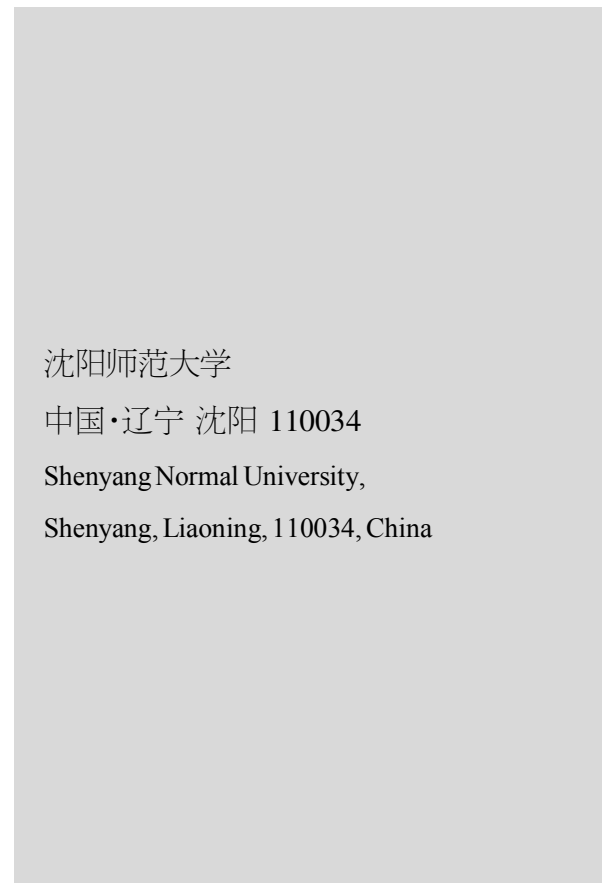

【摘要】当前, 中国特色社会主义进入新时代, 中华民族伟大复兴正处于关键时期。加强 以爱国主义为核心的国防教育, 对早日实现中华民族伟大复兴的中国梦, 具有重大而深远 的意义。论文结合沈阳师范大学的工作实践,通过对爱国主义教育与国防教育的关系、新 时代以爱国主义教育贯穿国防教育的意义、探讨爱国主义教育贯穿高校国防教育工作的 举措

【Abstract】Nowadays, the socialism with Chinese characteristics has entered a new era, and the great rejuvenation of the Chinese nation is in the critical period. Strengthening national defense education with patriotism at its core is of great and profound significance for realizing the Chinese dream of the great rejuvenation of the Chinese nation at an early date. Based on the working practices of Shenyang Normal University, this paper discusses the measures of patriotism education running through the work of national defense education in colleges and universities through studying the relationship between patriotism education and national defense education and the significance of patriotism education in national defense education in the new era.

【关键词】新时代; 爱国主义教育; 国防教育工作; 实践

【Keywords】 new era; patriotism education; work of national defense education; practice 【DOI】10.36012/sde.v2i3.1600

\section{1 引言}

“青年兴则国家兴, 青年强则国家强。”用习近平总书记的 话来说, 新时代的大学生是“整个社会力量中最积极、最有生 气的力量, 是国家的希望和民族未来, 担负着民族复兴的重任 和使命。”那么,如何将“自己的小我融入祖国的大我中”? 高 校的国防教育和爱国主义教育就起着重要的作用。

\section{2 国防教育与爱国主义教育}

\section{1 国防教育}

“国无防不立”, 可见国防对一个国家的重要。国防教育是 建设和巩固国防的基础, 是增强民族凝聚力、提高全民素质的 重要途径。全民国防教育的基本任务是: 普及国防知识, 培训 军事技能, 培育国防后备人才, 激发爱国热情, 强化国防观念, 增强民族自尊心、自信心、自豪感和凝聚力、向心力,提高公民
履行国防义务的自觉性。学校的国防教育是全民国防教育的 基础, 是实施素质教育的重要内容, 更是高校开展思想政治教 育的重要内容。

\section{2 爱国主义教育}

在新发布的《新时代爱国主义教育实施纲要》中提到: “爱 国主义是中华民族的民族心、民族魂, 是中华民族最重要的精 神财富，是中国人民和中华民族维护民族独立和民族尊严的 强大精神动力。”习总书记也曾说过: 弘扬爱国主义精神, 必须 把爱国主义教育作为永恒主题。要把爱国主义教育贯穿国民 教育和精神文明建设全过程。高校开展爱国主义教育, 是落实 立德树人根本任务，更是培养社会主义建设者和接班人的内 在要求。

\section{3 国防教育与爱国主义教育的辩证统一关系}

两者之间既有区别又有联系，区别是两者的基本任务不 同, 国防教育是使公民增强国防观念, 掌握基本的国防知识, 


\section{素质教育 Quality Education}

学习必要的军事技能, 激发爱国热情, 自觉履行国防义务。而 爱国主义教育是提高全民族整体素质的基础性工程，是引导 人们特别是广大青少年树立正确理想、信念、人生观、价值观, 促进中华民族振兴的一项重要工作。

\section{3 新时代以爱国主义教育贯穿国防教育 的意义}

中国共产党第十九次全国代表大会报告指出，中国现在 进入了新时代, 这就标志着中国的发展站到了新的历史起点 上, 中国特色社会主义进入了新的发展阶段。也就是说,近代 以来久经磨难的中华民族实现了从站起来、富起来到强起来 的历史性飞跃,开始进入历史新阶段。这个新时代是“承前启 后、继往开来、在新的历史条件下继续夺取中国特色社会主义 伟大胜利的时代; 是决胜全面建成小康社会、进而全面建设社 会主义现代化强国的时代; 是全国各族人民团结奋斗、不断创 造美好生活、逐步实现全体人民共同富裕的时代; 是中国社会 主要矛盾已经转化为人民日益增长的美好生活需要和不平衡 不充分的发展之间的矛盾的时代; 是全体中华儿女齐心协力、 奋力实现中华民族伟大复兴中国梦的时代; 是中国日益走近 世界舞台中央、不断为人类作出更大贡献的时代。”

在《中华人民共和国国防法》和《全民国防教育大纲》中， 都提到加强国防教育要以爱国主义为核心，发扬爱国主义精 神,可见爱国主义教育是国防教育的主要部分。习近平总书记 也说 “要把爱国主义教育贯穿国民教育和精神文明建设全过 程”, 培养具有远大理想信念、心怀爱国爱民之情、勇担时代责 任、敢于砥砺奋斗的接班人,是高校国防教育顺应新时代的育 人趋势。通过爱国主义教育, 培养学生的爱国之情, 树立强国 之志, 化为防国之行应是国防教育工作因事而化、因时而进、 因势而新的必然要求。

\section{4 构建爱国主义教育贯穿国防教育工作 的举措}

爱国主义教育作为推动社会前进的巨大力量，作为中国 培养社会主义新青年的基本要求，始终是高校开展思想政治 教育的重要内容, 是落实学校立德树人的根本途径미。2019年, 在庆祝中华人民共和国成立 70 周年的重要契机下,学校将爱 国主义教育作为年度的重点工作精心谋划, 积极推进。以深 人学习贯彻习近平新时代中国特色社会主义思想和中国共 产党第十九次全国代表大会精神为指导,依托学校“不忘初 心, 牢记使命”主题教育活动, 打出了一套形式新颖、内涵丰 富、独具特色的国防教育组合拳, 得到全校师生的热情参与 和积极点赞。

\section{1 以征兵工作为主阵地, 推进爱国主义教育常 态化、制度化}

大学生入伍是中国军队进行现代化建设, 实现强军目标 的重要途径。学校高度重视此项工作, 将其作为加强爱国主义 教育,推进国防建设的主要手段。

(1)营造氛围, 做好宣传动员。沈阳师范大学的征兵宣传工 作贯穿全年, 并充分利用各类媒体平台、主题活动、入学教育、 国防教育课、毕业生招聘会等,多形式、多阵地对大学生进行 广泛宣传教育, 明确在校大学生服兵役的重要意义,让学生了 解应征入伍是每个适龄公民应尽的义务, 号召学生把爱国之 心化为报国之行，用投笔从戎的家国情怀实现青春梦想。

(2)抓住节点, 做到情感育人。每年学校都会举行人伍大学 生新兵欢送会, 在弘扬学生投身军营、报效祖国的爱国精神之 时, 表达了学校的殷切嘱托和期望, 同时为学生发放了慰问大 礼包, 同学们备受鼓舞, 立志要发挥自身优势, 为新时代强军 梦做贡献, 回报母校, 回报祖国。此外, 今年学校号召二级学院 在国庆前夕为入伍大学生发送慰问信, 各学院通过实地走访、 寄送信件等方式向入伍学生表达了关怀和慰问, 让学生们深 受感动, 更加坚定了自己守护祖国的信念。以情感教育为主抓 手, 让爱国主义教育接地气, 暖人心, 落实效。

(3)军事社团, 发挥重要作用。让学生社团成为凝聚爱国共 识的核心力量。学校成立了校武装部领导下的军事类综合性 社团 “戎光学社”, 学社面向全校师生普及国防与兵器知识, 宣 传军事文化; 为有意愿参军的同学提供最真切的帮助; 为返校 的退伍大学生士兵提供最大程度的支持; 为参军入伍的大学 生士兵提供专业的政策解读。同时,学社还配合学校或其他组 织开展相关爱国主义教育, 国防教育, 征兵宣传等。学社的成 立为有志入伍的学生提供了归属, 为加强学校的国防教育, 激 发学生爱国情感提供了最有利的支撑。

\section{2 以榜样引领为主旋律,让爱国主义教育形象}

\section{化、鲜活化}

伟大时代呼唤伟大精神, 崇高事业需要榜样引领。学校从 多个层面和视角在大学生群体中弘扬榜样先进事迹, 发挥榜 样的示范效应, 引导更多学子向榜样学习, 树立崇高理想, 坚 定革命信念, 见贤思齐, 砥砺前行 ${ }^{[2]}$ 。

(1)以文化助推爱国主义教育向纵深发展。沈阳师范大学 音乐学院创作排演的大型交响组歌《新时代的精神脊梁—— 辽宁英模颂》奏响了时代华章。音乐会通过组歌的艺术形式, 生动形象地再现了雷锋、毛丰美、郭明义、罗阳、丁慧等一大批 英雄楷模的成长历程和光辉业绩, 以人们对英雄人物的怀念 
和颂扬为主线, 弘扬中国共产党员无私奉献精神和新时代辽 宁精神, 展现了辽宁人民忠诚于党、忠诚于祖国的坚定信仰和 担当奉献的家国情怀。用浓厚的艺术形式渗透了爱国主义教 育内容, 让观赏者在潜移默化中受到感染和熏陶。

(2)让雷锋精神永驻校园。每个时代都需要雷锋精神, 雷锋 精神一直是时代的最强音。为进一步弘扬雷锋精神, 庆祝新中 国成立 70 周年, 沈阳师范大学组织开展了辽宁大中小学“雷 锋精神永驻校园” 向新中国成立 70 周年献礼活动, 活动形式 新颖, 寓意深刻, 融快闪、演讲、大型表演等于一体, 活动还邀 请到雷锋班战士叶子贵做主题演讲, 整场活动用学生们喜闻 乐见的形式带来了一场别开生面的学习雷锋活动, 是一堂生 动鲜活的爱国主义教育公开课。让学生们充分认识到“雷锋精 神, 人人可学; 奉献爱心, 处处可为”, 营造了学习雷锋、崇尚雷 锋的良好社会氛围。

(3)以军中“姊妹花”引发学生关注热潮。2019 年 10 月 1 日 的国庆阅兵盛典惊艳了全世界, 在那些威武之师的成员中, 有 沈阳师范大学叶铭菲、李琳两位同学的飒爽英姿, 这两位同学 是沈阳师范大学培养出来的众多优秀学子中的代表, 为母校 争得了荣誉! 学校以两位同学为典型, 向全校学生进行宣传, 并希望广大学子能够以她们为榜样, 携笔从戎, 报效祖国, 在 军营的大熔炉中淬炼成钢, 在军队的大舞台上施展才华。此消 息得到了广大在校生的广泛传播和点赞,示范效应显著。

\section{3 以仪式教育为主动力, 将爱国主义教育渗透 于无形}

高校是一个充满仪式行为和活动的地方, 仪式教育为学 生带来安全感、秩序感、归属感、神圣感, 通过仪式教育让爱国 主义情感根植学生内心, 成为刻骨铭心的成长记忆, 让爱国主 义教育真正产生实效 ${ }^{[3]}$ 。

(1)让升旗仪式成为最朴素、长久的爱国教育形式。学校每 周一组织进行升国旗仪式，并以此作为爱国主义教育和集体 主义教育的重要手段。这种传承多年的仪式教育,让青年学子 在庄严的国旗下接受洗礼, 在国歌声中凝结爱国情怀, 增强了 学生的国家观念, 发扬了爱国主义精神。本学期初, 学校组织 开展了“同升国旗, 共唱国歌”师生开学第一课活动, 师生代表 分别做了国旗下的讲话, 涵养了家国情怀, 强化了责任担当。 师生共同接受了一次生动难忘的爱国主义教育, 青年学子表 示要把“爱国情、报国志”融入 “奋斗行”, 刻苦学习, 发奋图 强, 立志成才。

(2)全校上下一盘棋, 献礼祖国 70 华诞。时值中华人民共 和国成立 70 周年, 学校开展了多项庆祝活动, 向祖国献礼的 同时也更是以此重要时间节点对广大学子进行爱国主义教
育。十月一日学校党委组织假期在校学生集中收看国庆盛典, 共同歌唱祖国,营造了共庆祖国华诞、共享伟大荣光、共铸复 兴伟业的浓厚氛围; 学校组织广大学子走进乡村, 开展了大手 牵小手共唱《我和我的祖国》活动, 将爱国情怀的种子播撒到 孩子们的心间,与孩子们一起用歌声为祖国喝彩。与此同时, 各二级学院也精心组织开展了多项特色庆祝活动, 古生物学 院开展 “我和国旗同框”真情告白祖国活动; 文学院开展主题 诗朗诵微视频《读中国》; 国际商学院录制 MV《我爱你中国》。 各项活动制作精良, 精彩纷呈, 仪式感十足, 表达了学子们对 祖国最崇高的敬意和最真挚的祝福, 拳拳赤子心溢于言表!

\section{4 以大学生军事课为主渠道, 让爱国主义教育 课程化、系统化}

(1)沈阳师范大学高度重视课堂育人的重要性, 把军事课 纳人学校的教学计划, 安排学时和学分, 并且建设了一支高素 质的国防教育师资队伍, 开设了面向全校新生的军事理论课, 成立了军事理论课教研室。在军事理论教学过程中,将革命先 烈、民族英雄和仁人志士的光辉事迹、长征路的再现等红色文 化融入课堂教学, 让学生感受那段浴血奋战的历程, 感受中国 共产党领导全国人民和人民军队在中国革命各个历史阶段建 立功勋的艰辛和不易, 进而激发学生爱党爱国爱社会主义。

(2)把新生军训工作作为打通爱国主义情感的重要通道。 军训是新生人学的第一课, 更是锻造学生意志品质,培养爱国 爱校情怀的始发站。沈阳师范大学军训工作始终坚持育人与 强身相结合, 因材施训与普遍锻炼相结合的原则, 开展形式多 样,内容鲜活的军训活动。将方队训练、队列歌曲演绎、战术演 习、军体拳、棍术、擒敌拳等众多爱国主义元素融入军训之中, 用爱国主义教育串联军训各项工作，在百花齐放的训练中进 一步引导学生践行社会主义核心价值观，激发学生爱国卫国 意识,为今后更好健康成才、全面成才奠定坚实的基础。

爱国主义是一面具有最大号召力的旗帜，也是中华民族 的优良传统, 更是实现国家繁荣富强的不竭动力。在新时代 下, 国防教育工作应以爱国主义教育为抓手贯穿其中, 为进一 步落实立德树人的根本任务, 引导广大青年学生树立正确理 想、信念、人生观、价值观, 勤学修德, 踏实进取,为实现中华民 族伟大复兴的中国梦而不解奋斗。

\section{参考文献}

[1]杨冠英.加强以爱国主义为核心的高校国防教育对策研究 [J]. 读与写杂志 $2018(11): 74$.

[2]孙冬华.爱国主义教育背景下高校国防教育实效性研究[J].环 境构建,2019(1):58-59.

[3]廖希凯,林国乾.高校思想政治教育贯穿国防教育工作的实践 探索——以佛山科学技术学院为例[J].高校后勤研究,2019(3):86-88. 